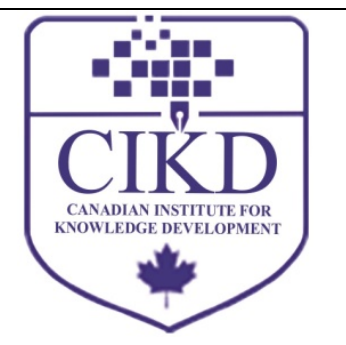

\title{
The Impact of Human Resource Management Practices on Innovative Ability of Employees Moderated by Organizational Culture
}

\author{
Qaiser Aman', Tayyba Noreen ${ }^{2 *}$, Imran Khan ${ }^{3}$, Rafaqet Ali ${ }^{4}$, Asim Yasin \\ ${ }^{1,4,5}$ Assistant Professor, Department of Management Sciences, COMSATS University Islamabad, Vehari \\ Campus \\ ${ }^{2}$ Lecturer, Department of Management Sciences, COMSATS University Islamabad, Vehari Campus \\ ${ }^{3}$ Assistant Professor/ Head of Department, Department of Management Sciences, COMSATS University \\ Islamabad, Vehari Campus
}

\begin{abstract}
Keywords:

Human Resource

Management, Innovative

Ability, Organizational

Culture

\section{Received}

09 March 2018

Received in revised form

22 October 2018

Accepted

24 October 2018

Correspondence:

tayybanoreen@ciitverhari.edu.pk

This study examines the relationship between human resource practices and innovation in the banking sector of Vehari and the moderation effects of organizational culture on this relationship. Structured questionnaires were used to collect data from respondents. Overall, 276 questionnaires were distributed and received back 151 (response rate 54\%). The independent variable has six human resource practices: Reward strategy, recruitment strategy, performance appraisal, career oriented trainings, performance oriented trainings and career management. The dependent variable is innovation in banks and the moderator variable is organization culture. This study found a partial support for the relationship between human resource practices and innovation with reward strategy, recruitment strategy. The performance appraisal was significant predictor of innovation and career management. The performance oriented trainings and career oriented trainings were insignificant predictors of innovation. The organization culture moderated this relationship negatively.
\end{abstract}

In today's continuously changing business environment, organizations need to develop a human resource system that can help organizations in fostering innovation and creativity 
among employees. Organizations are developing strategies based on innovation so that they can remain in competition and can get sustainable competitive advantage. They are developing Human Resource Management practices (HRM) and establishing a culture, favorable for the development and implementation of innovative ideas.

For success of an organization, HRM practices play an important role with organization culture, conducive to development of innovative ability of the employees. HRM practices are those policies which an organization needs to deal with its employees and other persons. Many studies found that organizations with unique human resources lead to best performance not only of employees individually but also of organization collectively. HRM practices mostly include recruitment, selection, training, compensation administration, performance and appraisal management and career management, etc. HRM practices which develop innovation and creativity in employees are considered important for success of organization. Previous research has shown that organizations which have not shown innovative behavior are left far behind from the organizations with innovative abilities of their employees. Amo and Kolvereid (2005) defined innovation as "An initiative from employees concerning the introduction of new products, new processes, new markets and combination of such into the organization".

HRM practices are those practices which an organization develops for recruiting, retaining and securing most capable and potential candidates for running its operations successfully. The organizations which are unable to keep innovative abilities in their personnel, they obsolete with the time and lack in competitive advantage. In the literature, the relationship between HRM practices and innovation is twofold, i.e., HRM practices can foster innovative abilities of employees and at the same time the innovative ability of employees can also, up to some extent, develop HRM practices of the organizations.

Different variables moderate the relationship between HRM practices and innovation such as knowledge management (Mario \& Donate, 2014), Knowledge (Alvaro, 2009), leadership style, organization strategy, structure and culture. The importance of HRM practices was recognized in 1980s and later on their empirical relation with performance of the organization was found. A firm with better HRM practices has more chances to obtain more competitive advantage than its rival firms.

Nowadays, organizations need a labor force with innovative abilities so that they can produce products and provide services as per demands of the markets in revolutionary business environment. The fundamental concern of the organization is to uphold a fit between its offerings to market and what environment dictates (Liao, Kickul, \& Ma, 2009). It is radical and thoughtful attempt to introduce some variations in products, services or processes or in organization (Leede \& Looise, 2005).

Innovative ability is important in building and bringing new products and services. In literature, innovation has been described by several different ways. Thomson (1965) has defined innovation as the generation of the ideas and thoughts, acceptance of ideas and then implementation of ideas successfully. Each component of this definition requires innovative ability for instance generation of new ideas requires thinking in new ways and thinking out of box. Idea acceptance requires complete change of mindset because there may be resistance from the employees and implementation requires development of new skills and change in overall environment. Therefore, innovation must be implemented across the organization not 
on step by step basis. Innovation implemented step by step basis may lose its effectiveness because other aspects of organization may not work in a coherent way with dimension of the organization which is affected by change. Innovation is the process that produces new products or services or old products or services with enhancing features at low cost or at same cost with better quality. Different aspects of innovation are: a) Innovation is a process to produce a totally new products or services, b) Innovation of way through which existing products can be produced through better management of resources, it may include technological innovation and administrative innovation, and c) Innovation may combine resources in order to get magnified effect rather than using the resources individually.

The purpose of HRM is to provide an environment which is conducive enough to develop skills and competencies of employees that help them act innovatively. Thinking about strategy based on innovation organizations need to have creative employees. The employees who are willing to take risks, are flexible and have the ability to survive in uncertain and ambiguous situation (Valle \& Jimenez, 2005) and There will be best fit in strategy of organization and skills of such type of employees. If the organizations lack innovative employees, then going outside the organization for potential employees can help implement innovative strategy.

\section{Research Problem}

Banks are now facing a complex environment with cut throat competition. The success of banks is not possible without the development of new products and services which is possible only with innovative abilities of employees. But the problem is: what are the factors responsible in developing the innovative abilities in employees? This study empirically investigates the types of HRM practices that are linked with innovation and role of culture with respect to this relationship.

\section{Research Questions}

1. Do HRM practices develop innovative abilities of the employees or not?

2. Does organization culture moderate the relationship between human resource practices and innovative abilities of the employees?

\section{Objectives of the Study}

1. To test and explain the relationship between HRM practices and Innovative ability of employees.

2. To find out the moderating effect of organization culture on the relationship between HRM practices of the organization and innovative ability of employees.

\section{Significance of the Study}

The purpose of this study is to determine whether there exists a relationship between HRM practices and innovation in the organization and impact of organization culture on that relationship. Most studied on this relationship are conducted in countries other than Pakistan and the published research lacks in the banking sector. This study will help the banking managers to find the appropriate HRM practices that promote the innovative ability of employees of banking sector of Vehari. 


\section{Literature Review}

It is evident from literature that Human Resource Management encourages employee commitment which leads to organization effectiveness (Agarwala, 2003). Firm's success or failure depends on the ability of its human force because it is only human who can use its human and non-human assets efficiently and effectively.

Previous research studies have shown that HRM practices have significant impact on organization innovative behavior not only in service organizations but also in manufacturing organizations. Some studies supported the relationship of individual HRM functions such as training (Kachelmeier \& Williamson, 2010), compensation (Hon \& Lu, 2014) performance management with innovation. HRM practices have an influence on organization performance mediated by organizational commitment (Agarwala, 2003). Dhar (2015) has found an indirect positive relation between high performance of human resource practices and innovative behavior. Success of an enterprise depends on its ability to affect motivation of employees and behavior to improve knowledge sharing practices necessary for motivation (Özbă̆, Esen, \& Esen, 2013).

Many studies are available in literature to find antecedents of innovation in organization. Wan, Ong, and Lee (2005) conducted a study about an innovation in Singapore to find the causes of innovation and concluded a positive relationship between innovation and decentralization of structure and decision making. They found that innovation and creativity is important for success of the organization, which leads to preparedness to take risks and willing to share ideas and information.

Innovative capabilities may be developed among employees by style and ways of leading. Gumusluog and Ilsev (2009) conducted a study to find the relationship between transformational leadership and innovation with moderating effect of external and internal support for innovation in 43 Turkish software firms. They concluded that there exists a strong relationship between Leadership and innovation and internal support does not moderate this relationship but external support does. Innovation may be of various types; Boer and During (2001) explained three types of innovation: product innovation, process innovation and organizational innovation. The innovation was discussed in literature as change processes. Leede and Loose (2005) also discussed two steps of the change process initiation and implementation with sub phases as "agenda setting, matching, redefining, restructuring, clarifying and routinizing.

The universal or best practice reveals that in organizations, some HRM practices always act in a better way than others, therefore all organization should implement these practices (Marchington, Mick, \& Grugalis, 2000). The scholars who support the contingency approach contend that in order to work effectively HRM practices must work in a coherent way with other aspects of the organization (Beugelsdik, 2009). Delery and Doty (1996) noted that there must be horizontal fit (internal consistency of HR practices) and vertical fit (must be consistent with other aspects like strategy, structure, etc.) They called it configurational approach.

Human resource management is a set of integrated system that is developed to manage employees in order to achieve organizational strategic and operational goals (Birasnav \& Rangnekar, 2009). HRM Practices mostly include recruitment, selection of competitive and 
knowledgeable employees, development of essential skills and knowledge, performance appraisal, developing ability to show innovative behavior and development of their career plan. Organizations will invest only on employees to make them human capital when employees will have ability to add more economic value to the firm after acquiring the human capital (Birasnav \& Rangnekar, 2009). Human capital is knowledge, abilities, capacities, skills, and innovative ability of employees (Bontis, 2001). Organizations try to develop some HRM practices which foster the capabilities of employees to use them for getting sustainable competitive advantages.

Organization commitment of the employees is also affected by HRM practices. Meyer and Smith (2000) found that HRM practices strongly influence the commitment of employees with mediated effect of procedural justice and perceptions of organizational support. They collected data from 281 employees from different organizations through developed questionnaires. Different HRM constructs such as performance appraisal, career development and trainings were used in this research study. Once commitment of employees is developed, it can promote innovative ability of employees. HRM practices produce knowledge and this knowledge can enhance through the development of commitment of employees (Ordaz, Cruz, Ginal, \& Cabrera, 2011).

Knowledge of employees has also tendency to affect the relationship between HRM practices and innovation. Alvaro (2009) found that knowledge of employees mediates the relationship between HRM practices and innovation in the organization and performance of the employees. On the basis of data collected, 7 points Likert Scale from 86 respondents' firms, they concluded that HRM practices increase the uniqueness of knowledge and this unique knowledge is positively related to the level of innovation and then innovative ability is positively related to performance of employees. But they ignored what type of knowledge, job related technical knowledge or overall knowledge of the organization, is associated with innovation?

One of the important factor in the organizations that stimulates innovation in the organization is organization culture. In literature, culture has been divided into two categories as explicit culture and implicit culture. Organization culture acts as mediator between relationship of transformational leadership and change and innovation (Sorros, Cooper, \& Santora, 2008). Obgonna and Harris (2000) empirically observed the relationship between participative leadership and innovative culture for predicting organization performance.

There is an ambiguity in literature and divergence of opinion about a positive relationship between recruitment and innovation. Recruitment and selection are important tools for selecting employees with innovative abilities. The type of people who are selected through external recruitment represents the ideology and views of the management (Martins \& Terblanche, 2003). People through external recruitment come into the organization with new ideas and skills that should develop innovation and new solutions. In order to encourage innovation in organizations, it is important for the organization to recruit employees with creative mind and skills, and those who have ability to identify gaps. To that end, firms must have sophisticated and technical practices such as psychological and psychometric tests, and specific interviews (Shipton, Fay, West, Patterson, \& Birdi, 2005). 
Trainings whether in educational institutes or work environment influence the innovative ability of employees. Employees are interested in trainings because of future growth, status and increased responsibilities (Bauernschuster, Falck, \& Heblich, 2009). Trainings change attitudes and can have capabilities to develop innovative abilities in employees. Bauernschuster et al., (2009) tested the empirical relationship between continuous trainings and innovation. They found that trainings provide wide variety of knowledge thus leading to development of innovative ability of employees.

In organizations, if new ideas are respected and rewarded, then that will increase the probability of increasing innovative ability of employees. Rewards strategy either fosters or inhibits the creativity and innovative ability of employees (Shipton et al., 2005). This argument is in line with the reinforcement theory of motivation. Rewards motivate the employees and motivation forces them to take risks and thus risk taking will lead to promotion of innovative ability of employees. When employees are assigned difficult and new complex tasks, they will try to find some solution, this will increase their ability to think analytically and their innovative ability will be increased.

Performance appraisal is a process through which higher level managers evaluate the performance of subordinate employees. The purpose of this is to provide feedback to employee and make an assessment where improvements are needed. Performance Appraisal creates challenges and can increase employees' motivation to get engaged in innovative activities (Valle \& Jiménez, 2005). The process of performance appraisal determines what is expected from employees and what actually they are doing. Performance appraisal can help employees in developing new ways of doing their work or finding some ways in removing hurdles that keeps them away from reaching up to par performance. In this way performance appraisal stimulates the capability of innovation in employees which is limited to their performance. But the question is that if performance appraisal is enough to produce capability of employees which can lead them to innovate products/services or processes thorough which products or services are produced. Shipton et al. (2005) found that performance appraisal that promotes knowledge and skills can encourage creativity and innovation among employees. Career management is long term and continuous process which helps employees in ensuring a long term successful career.

\section{Theoretical Framework and Hypotheses Development}

It is evident from literature that HRM practices and innovation are significantly correlated. But among researchers, three is a disagreement about different practices under the cover of HRM practices. Training, performance based rewards, and team development are positively associated with innovation (Lau \& Ngo, 2004). Product innovation is produced in organizations by employee empowerment, task autonomy, and flexible working hours. The incremental innovation can be enhanced by Performance based pay, schooling, and training (Beugelsdik, 2009).

Thinking about strategy based on innovation, organizations need to have creative employees: the employees who are willing to take risks, are flexible and have ability to act/survive in uncertain and ambiguous situation (Valle \& Jiménez, 2005). There will be best fit in strategy of organization and skills of such type of employees. If such type of employees is 
not available, then going outside the organization for potential candidates/employees can help implement innovative strategy. HRM Practices improve skills, abilities and aptitudes. HRM has now become a crucial element in developing of innovational activities. It promotes innovation by assisting employees' in gaining, relocating and institutionalizing knowledge and information (Shipton et al., 2005).

The hypotheses of this study are given below and Figure 1:

$\mathbf{H}_{1 \mathbf{a}}$ : There is positive relationship between recruitment strategy and innovation.

$\mathbf{H}_{\mathbf{1}}$ : Training (performance oriented trainings \& career oriented trainings) and innovation in organization are positively associated.

$\mathbf{H}_{1 \mathbf{c}}$ : Positive performance appraisal encourages innovation in employees.

$\mathbf{H}_{\mathbf{1 d}}$ : Career Management is found to have an impact on innovation.

$\mathbf{H}_{1 \mathbf{e}}$ : Reward Strategy influences the innovation in positive way.

$\mathbf{H}_{2}$ : Organization Culture moderates the relationship between HRM practices and innovation positively.

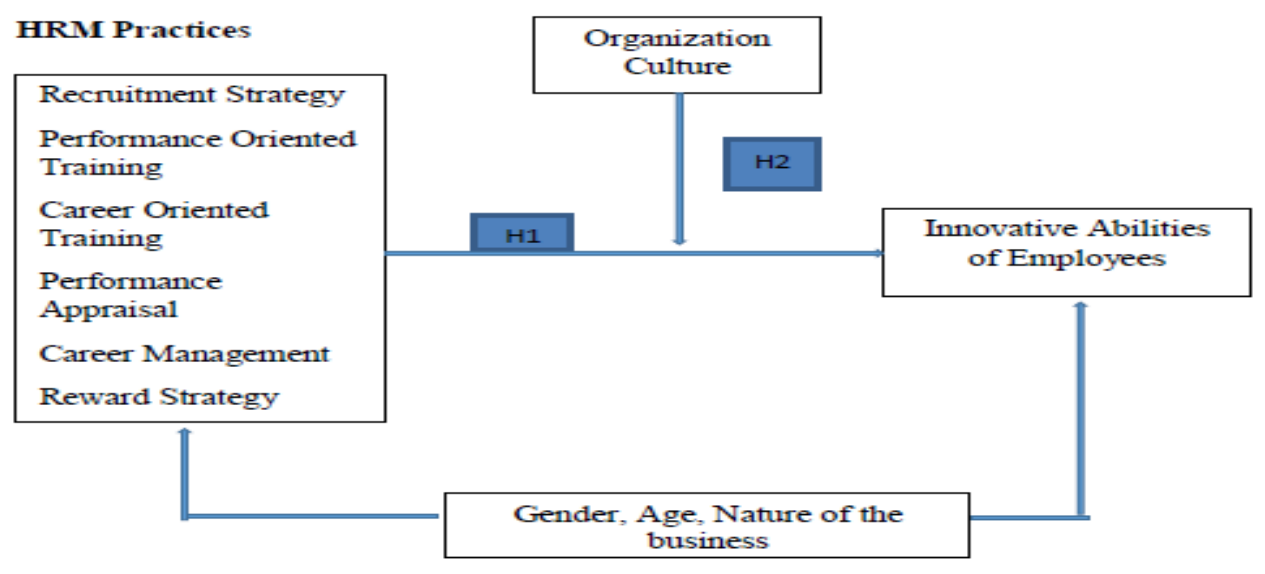

Figure 1. hypotheses of this study

\section{HRM Practices}

The improvement of new Human Resource Management function where human experience is critical and knowledge can be generated, shared and leveraged in learning processes of lived experiences, and can lead to development of new skills and innovative ability of employees (Prieto Pastor, Perez Santana, \& Martín Sierra, 2010). Human resource practices can be directly attributed to three kinds of innovation, i.e., product innovation, process innovation and administrative innovation via exploration rather than taking advantage (Ling \& Nasirudin, 2010).

\section{Population and Sample}

Population of this study included employees of all branches of all banks located in District Vehari (Vehari city, Mailsi and Burewala). Different private local and foreign banks have opened its branches in District Vehari. Due to financial and time limitations, it was not possible to collect data from whole population; therefore, cluster and simple random sampling 
approaches were used to draw a suitable and representative sample. The population were grouped into three clusters on the basis of operations performed by them: i. conventional banking, ii. Islamic banking, and iii. Microfinance banks.

\section{Data Collection and Measurement}

\section{Independent Variable}

In this study, the independent variable is HRM practices. The Recruitment Strategy, Performance oriented Training, Career Oriented Training, Career Management, Performance Appraisal, and Reward Strategy were used according to the constructs of Human Resource Management.

HRM practices were measured by using questionnaire used by Birasnav and Rangnekar in 2009 (with some modifications) on 5-point Likert Scale which included 28 questions but in this study only 21 questions were used.

\section{Dependent Variable}

Dependent variable in this study is innovative abilities of employees. Innovative ability of employees means that employee can think about new ideas and then they have the ability to turn these ideas into reality. For example, someone in the organization can think about new structure or design of a product which is more attractive and useful to customers. Innovative ability of employees depends on organizational strategy; employees own nature and ability, leadership, organization structure and culture, etc.

\section{Moderating Variable}

A moderating variable is a variable that influences or moderates the relation between two other variables and thus produces an interaction effect. Moderation is a process that indicates that relationship between independent and criterion variable is a function of moderator variable (1, Henseler, \& Ringle, 2011). Organization culture was used as a moderating variable in this study and it was measured by Developmental culture' scale of the Michigan competing values framework which includes four items addressing the innovation, risk taking, and commitment of organization to innovation.

\section{Control Variables}

Control variables are remained constant in an experiment and if they are changed, their change can affect the relation between other variables. Gender, age groups and kind/nature of business are control variables in this study.

\section{Data Analysis and Interpretations}

The moderation analysis using SPSS 16 was employed in this study. In total, 276 questionnaires were distributed, out of which 159 were returned in the specified time. The reliability of the data by calculating Cronbach's Alpha was checked. The value of Cronbach's Alpha for HRM practices was .83 which is greater than the generally satisfactory value indicating that data is reliable and internally consistent. Similarly, values of Cronbach's Alpha were .71 and .67 , respectively. Then independent sample tests were conducted to check the 
significant difference of control variables which shows that there was no difference of conditions of gender (male $\&$ female) on the response. ANOVA test was conducted to check whether the response was affected or not by different conditions of age groups and nature of business (conventional banks, Islamic banks, microfinance banks). Regression analysis was conducted to test the relationship between dependent and independent variables. Association between dependent and predictor variable can be best explained by regression analysis (Schneider, Hommel, \& Blettner, 2010). Sometimes, there are also other factors which increase, decrease or change the nature of relationship between independent and dependent variable. After testing the relationship between HRM practices and innovation through regression analysis, the impact of moderator variable, organization culture, was tested in SPSS. Interaction term was created by multiplying the independent variable with moderator variable. Moderation is normally measured by succeeding equation (Preacher, Rucker, \& Hayes, 2007).

$$
\mathrm{Y}=\mathrm{a}+\beta \mathrm{x} 1+\beta 2 \mathrm{~m}+\beta 3 \times 1 \mathrm{~m}+\mathrm{r},
$$

Where $\mathrm{Y}=$ dependent variable, $\mathrm{X}=$ independent variable, and $\mathrm{m}=$ moderator variable

By implementing this equation into our analysis,

$$
\text { Inn }=a+\beta 1 \text { HRMp }+\beta 2 \text { OC }+\beta 3 \text { HRMp.OC }
$$

Where, Inn indicates the innovation, the dependent variable of this study; HRM practices shows the Human Resources Management practices, the independent variable of this study; and OC stands for Organization Culture, the moderated variable.

\section{Moderated Regression Analysis}

Regression analysis was conducted to test the relationship between independent variable, HRM practices and dependent variable, innovative ability of employees. As indicated in Table 1, $43.7 \%$ variations have been explained by control variables and human resource practices and innovation. $0.8 \%$ variation has been explained by control variables and remaining $42.9 \%$ was caused by HRM practices. After making adjustment based on number of predictors, model summary of the analysis indicated that $40 \%$ of the variation in the innovation in organization was due to HRM practices and control variables. A total of $1 \%$ variation has been explained by control variables and 39\% has been explained by HRM practices (Reward Strategy, Career Oriented Training, Performance Appraisal, recruitment Strategy and Performance Oriented Trainings). The significant value $(p=.000)$ indicates that model is valid which means that HRM practices are important predictors of innovation in the organization whereas this type of link could not be proved in case of control variables.

Table 1

Model Summary of Regression Analysis

\begin{tabular}{cllllll} 
Model & $R$ & $R 2$ & Adjusted $R 2$ & $S E$ & $F$ & $p$ \\
\hline 1 & $.09^{\mathrm{a}}$ & .008 & .01 & .74 & 12.25 & .000 \\
2 & $.66^{\mathrm{b}}$ & .43 & .40 & .57 & 25.56 & .000 \\
\hline
\end{tabular}

a. Predictors: (Constant), Nature of Business, Bank Type, Gender

b. Predictors: (Constant), Nature of Business, Bank Type, Gender, Performance Appraisal, Career Management, Career Oriented Training, Performance Oriented Training, Recruitment strategy, Rewards Strategy

This section elaborates upon HRM practices that are relevant to innovation. According to Table 2, regression equation can be made as following: 


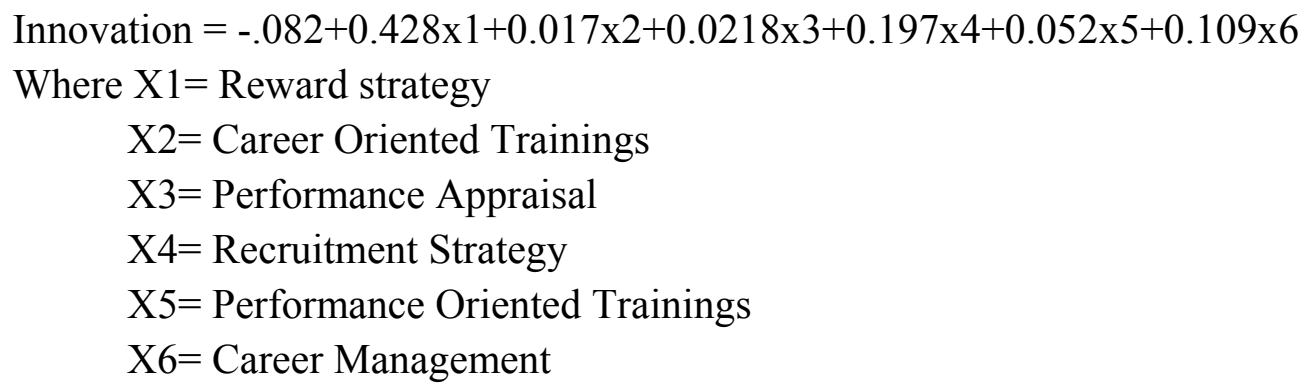

As presented in Table 2, all control variables are insignificant and do not have any or have a little impact on innovation. Reward strategy has significantly predicted innovation in the organization with $B=.24$ which shows that 1 percent change in reward strategy will lead to .24 $\%$ change in innovation, i.e., $1 \%$ increase in rewards will lead to $24.8 \%$ increase in innovative ability of employees. The significant value, $p=.003$ shows that reward strategy is significantly associated with innovation.

In case of career oriented trainings, $B=.017$ means that $1 \%$ change in trainings will lead to $1.7 \%$ change in innovative abilities of employees. But in this study career oriented trainings ( $p$ $=.75$ ) are not significant predictor of innovative abilities in banks. Similarly, the performance appraisal has also been found to be have a positive relation with innovative ability of employees. $B=.218$ indicates that one percent change in performance appraisal will enhance innovation in organization by $21.8 \%$. the significant value, $p=.002$, also indicates that performance appraisal is significantly associated with innovation in the banking sector of Vehari. Likewise, recruitment strategy is also positively associated with innovative ability of employees. $B=.197$ shows that $1 \%$ improvement in recruitment strategy will lead to select employees with $19.7 \%$ higher in innovative abilities and it is also a significant predictor of innovation with $p=.04$. Remaining three constructs of HRM practices (performance oriented trainings, career oriented trainings and Career Management with $p=.757, p=.496$ and $P=$ .133, respectively) are not associated significantly with innovation. This study accepts Hypotheses $\mathrm{H}_{1 \mathrm{a}}, \mathrm{H}_{1 \mathrm{c}}$, and $\mathrm{H}_{1 \mathrm{e}}$. Remaining hypotheses $\mathrm{H}_{1}$, and $\mathrm{H}_{1 \mathrm{~d}}$ could not be found statistical support. 
Table 2

Coefficients of Regression Analysis

\begin{tabular}{|c|c|c|c|c|c|c|}
\hline \multirow[b]{2}{*}{ Model } & & \multicolumn{2}{|c|}{ Unstandardized Coefficients } & \multirow{2}{*}{$\begin{array}{c}\text { Standardized } \\
\text { Coefficients }\end{array}$} & \multirow[b]{2}{*}{$t$} & \multirow[b]{2}{*}{$p$} \\
\hline & & $B$ & $S E$ & & & \\
\hline \multirow[t]{4}{*}{1} & (Constant) & 3.893 & .38 & & 10.08 & .000 \\
\hline & Gender & -.059 & .16 & -.02 & -.34 & .728 \\
\hline & Bank Type & -.102 & .15 & -.05 & -.65 & .515 \\
\hline & Nature of Business & -.060 & .07 & -.06 & -.79 & 431 \\
\hline \multirow[t]{10}{*}{2} & (Constant) & -.082 & .51 & & -.16 & .873 \\
\hline & Gender & .033 & .13 & .01 & .25 & .802 \\
\hline & Bank Type & .213 & .12 & .11 & 1.69 & .092 \\
\hline & Nature of Business & .028 & .05 & .03 & .47 & .635 \\
\hline & Rewards Strategy & .248 & .08 & .25 & 3.04 & .003 \\
\hline & Career Oriented Training & .017 & .05 & .02 & .31 & .757 \\
\hline & Performance Appraisal & .218 & .06 & .24 & 3.17 & .002 \\
\hline & Recruitment strategy & .197 & .06 & .22 & 2.86 & .004 \\
\hline & $\begin{array}{l}\text { Performance Oriented } \\
\text { Trainings }\end{array}$ & .052 & .07 & .05 & .68 & .496 \\
\hline & Career Management & 109 & .07 & .12 & 1.51 & 133 \\
\hline
\end{tabular}

Note: Dependent Variable: Innovation

As indicated in Table 3, organization culture explains a $24.7 \%$ variation in innovation in banks of district Vehari. After making adjustment based on number of predictors, this study found that organization culture has explained $24.2 \%$ variations in innovation.

Table 3

Model Summary for Regression Analysis between Organization Culture and Innovation

\begin{tabular}{|c|c|c|c|c|c|c|}
\hline Model & $R$ & $R^{2}$ & Adjusted $R^{2}$ & $S E$ & $F$ & $p$ \\
\hline 1 & $.497^{\mathrm{a}}$ & .247 & .242 & .64426 & 9.361 & .000 \\
\hline
\end{tabular}

a. Predictors: (Constant), Organization Culture

Table 4 shows that organization culture $(p=.000)$ is significant predictor of innovative abilities of employees.

Table 4

Coefficients of Regression Analysis between Organization Culture and Innovation

\begin{tabular}{|c|c|c|c|c|c|c|}
\hline \multirow[b]{2}{*}{ Model } & & \multicolumn{2}{|c|}{ Unstandardized Coefficients } & \multirow{2}{*}{$\begin{array}{c}\text { Standardized } \\
\text { Coefficients } \\
\beta\end{array}$} & \multirow[b]{2}{*}{$t$} & \multirow[b]{2}{*}{$p$} \\
\hline & & $B$ & $S E$ & & & \\
\hline \multirow[t]{2}{*}{1} & (Constant) & 1.74 & .26 & & 6.71 & .000 \\
\hline & Organization Culture & .478 & .06 & .49 & 6.98 & .000 \\
\hline
\end{tabular}

a. Dependent Variable: Innovation

As presented in Table 5, interaction term explains only $6.2 \%$ variation in dependent variable of this study. After making adjustment based on number of predictors that actually impact the dependent variable, it has explained 5.2\% variation in innovation. 
Table 5

Model Summary for Regression Analysis of Moderator (Interaction Term) and Innovation

\begin{tabular}{ccccccc}
\hline Model & $R$ & $R^{2}$ & Adjusted $R^{2}$ & $S E$ & $F$ & $p$ \\
\hline 1 & $.249^{\mathrm{a}}$ & .062 & .052 & .75 & 6.39 & .000 \\
\hline a. Predictors: (Constant), Organization Culture & & &
\end{tabular}

Table 6 shows that organization culture $(\beta=-.010, p=.003)$ moderates the relationship between HRM practices and innovation negatively. Therefore, this study cannot accept the hypotheses stating that organization culture moderates the relationship between human resource practices and innovation positively.

Table 6

Coefficients of Regression Analysis of Moderator (Interaction term) and Innovation

\begin{tabular}{|c|c|c|c|c|c|c|}
\hline \multirow[b]{2}{*}{ Model } & & \multicolumn{2}{|c|}{ Unstandardized Coefficients } & \multicolumn{3}{|l|}{ Standardized Coefficients } \\
\hline & & $B$ & $S E$ & $\beta$ & $t$ & $p$ \\
\hline \multirow[t]{2}{*}{1} & (Constant) & 3.554 & .05 & & 59.84 & .000 \\
\hline & Moderator & -.010 & .003 & -.24 & -3.03 & .003 \\
\hline
\end{tabular}

a. Dependent Variable: Innovation

\section{Discussion}

This study found that organization culture is weak moderator of the relationship between the independent and criterion variable and it shows that the higher the rigidity and non-flexibility of the organization culture the lower the relationship between human resource practices and innovation and vice versa. Our results are contrary to Wei, Liv, and Herndon's (2011) results because they found that Organization Culture moderates the relationship between strategic human resource practices and product innovation. This is because their study was conducted on corporate sector but our study was conducted on banking sector of Vehari; therefore, there is a difference between culture of a corporation and culture of a bank. Bankers perform structured jobs and there is no flexibility and adaptability of innovation in culture of banks. The second reason may be because of difference between overall culture of China and Pakistan and the individual differences of perception, organizational strategy, and organizational structure, etc.

This study also found that reward strategy is positively related with innovation in banks of district Vehari. It means that higher the quantity and quality of rewards, higher will be chances of developing innovative ability of employees. Effective Reward system created on performance and knowledge basis would help employees to think in unique ways which may cause them to act more innovative ways (Tan \& Nasurdin, 2011).

Recruitment strategies also have a positive impact on innovation in banks of Vehari. Innovation oriented recruitment strategies attempt to select employees with innovative abilities. This study confirms this relationship between recruitment strategy and innovation empirically. Contrary to our anticipations and expectations, trainings have no significant impact on innovation. The reasons for this unusual link may be that trainings offered in banks was related to routine tasks without having any link to innovation. In this study, career management is also insignificant predictor of innovation. 


\section{Conclusions}

It can be concluded that reward strategy, recruitment strategy and performance appraisal are significant predictor of innovation whereas career management, performance oriented trainings and career oriented trainings are not significant predictor of innovation in banks of district Vehari. Organization culture moderates the relationship between human resource practices and innovation negatively, i.e., a strong culture would weaken the relationship between human resource practices and innovation and a weak, flexible and conducive innovation and new practices would lead to strong relationship. This study will contribute to the existing human resource literature by determining moderating effects of culture on the relationship between human resource practices and innovation. In workplace, this will help the managers to select most appropriate human resource practices for the development of innovative abilities of employees.

\section{References}

Agarwala, T. (2003). Innovative human resource practicesand organizational commitment: An empirical investigation. International Journal of Human Resource Management, 14(2), 175-197.

Alvaro, L. (2009). Knowledge as a mediator between hrm practices and innovative activity . Human Resource Managemet, 485-503.

Amo, B. W., \& Kolvereid, L. (2005). Organizational strategy, individual personality and innovation behavior. Journal of Enterprising Culture, 13(1), 7-19.

Bauernschuster, S., Falck, O., \& Heblich, S. (2009). Training and innovation. Journal of Human Capital, 323-353.

Beugelsdik, S. (2009). Strategic human resource practices and product innovation. Organization Studies, 822-847.

Birasnav, \& Rangnekar. (2009). Structure of human capital enhancing: human resource practices in India. International Journal of Business and Management, 4(5), 226-238.

Boer, H., \& During, W. (2001). Innovation, what innovation? A comparison between product, proccess and organizational innovation. International Journal of Technology Management, 22(1-3), 83-107.

Bontis, N. (2001). Assessing knowledge assets: a review of the models used to measure intellectual capital. International Journal of Managemenrt Reviews, 3(1), 41-60.

Dhar, R. L. (2015). The effects of high performance human resource practices on service innovatve behaviours. International Journal of Hospitality Management, 51, 67-75.

Gumusluog, L., \& Ilsev, A. (2009). Transformational leadership and organizational innovation: the role of external and internal support for innovation. Product Innovation Management, 26(3), 264-277.

Hon.Y. A., \& Lu. H. (2014). Are We paid to be creative? The effects of compensation gap on creativity in an expatriate context. Journal of World Business, 50(1), 159-167.

Kachelmeier, S. J., \& Williamson, M. G. (2010). Attracting creativity: The initial and aggregate effects of contract selection on creativity-weighted productivity. The Accounting Review, 85(5), 1669-1691.

Lau, C. M., \& Ngo, H. Y. (2004). The HR system, organizational culture and product innovation. International Business Review, 13(6), 685-703.

Leede, J. K., \& Loose, J. K. (2005). Innovation and HRM: Towards an integrated framework. Creativity and Innovation Management, 14(2), 108-117.

Liao, J., Kickul, J. R., \& Ma, H. (2009). Organizational dynamic capability and innovation: An empirical examination of internet firms. Journal of Small Business Management, 47(3), 63-86.

Ling, T. C., \& Nasirudin, M. A. (2010). HRM practices and organizational innovation: An empirical study in Malasyia . The Journal of Applied Business Research, 105-116.

Mario, J., \& Donate, J. D. (2014). The role of knowledge-oriented leadership in knowledge management practices and Innovation. Journal of Business Research, 68(2), 360-370.

HYPERLINK "http://www.emeraldinsight.com/author/Martins\%2C+EC" Martins. E. $\quad$ C., HYPERLINK "http://www.emeraldinsight.com/author/Terblanche\%2C+F" \& Terblanche, F. (2003). Building organizational culture that stimulates creativity and innovation. European Journal of Innovation Management, 6(1), 64-74. 
Meyer, J., \& Smith, C. A. (2000). HRM practices and organizational commitment. Candanian Journal of Administrative Sciences, 17(4), 319-331.

Obgonna, \& Harris. (2000). Leadership style, organization culture and performance: Empirical evidence from UK companies. International Journal of Human Resource Management, 11(4), 766-788.

Ordaz, C. C., Cruz, J. G., Ginal, S. E., \& Cabrera, R. (2011). The influence of human resource management on knowledge sharing and innovation in Spain: The mediating role of affective commitment. The International Journal of Human Resource Management, 22(7), 1442-1463.

Özbağ, G. K., Esen, M., \& Esen, D. (2013). The impact of HRM capabilities on innovation mediated by knowledge management capability. Procedia-Social and Behavioral Sciences, 99, 784-793.

Preacher, K. J., Rucker, D. D., \& Hayes, A. F. (2007). Addressing moderated mediation hypotheses: Theory, methods, and prescriptions. Multivariate Behavioral Research, 42(1), 185-227.

Prieto Pastor, I. M., Perez Santana, M. P., \& Martín Sierra, C. (2010). Managing knowledge through human resource practices: Empirical examination on the Spanish automotive industry. The International Journal of Human Resource Management, 21(13), 2452-2467.

HYPERLINK "https://www.researchgate.net/profile/Marko_Sarstedt" Sarstedt, M., Henseler, J., \& Ringle, C. M. (2011). Multi-group analysis in partial least squares (PLS) path modeling: Alternative methods and empirical results. Measurement and Research Methods in International Marketing, 22, 195-218

Schneider, A., Hommel, G., \& Blettner, M. (2010). Linear regression analysis. Deutsches Ärzteblatt International, 107(44), 776-782.

Shipton, H., Fay, D., West, M., Patterson, M., \& Birdi, K. (2005). Managing people to promote innovation. Creativity And Innovation Management, 14(2), 118-128.

Sorros, J. C., Cooper, B. K., \& Santora, J. C. (2008). Building a climate for innovation through transformational leadership and organizational culture. Journal of Leadeship and Organizational Studies, 15(2), 145-158.

Tan, C. L., \& Nasurdin, A. M. (2011). Human resource management practices and organizational innovation: Assessing the mediating role of knowledge management effectiveness. Electronic journal of knowledge management, 9(2), $155-167$.

Thompson, V. A. (1965). Bureaucracy and innovation. Administrative Science Quarterly, 10, 1-20.

Valle, S., \& Jiménez, J. (2005). Innovation and human resource management. International Journal of Manpower, 26(4), 364381

Wan, D., Ong, C. H., \& Lee, F. (2005). Determinants of Innovation. TechInnovation, 25(3), 261-268.

Wei, L. Q., Liv, J., \& Herndon, N. (2011). SHRM and Product Innovation: The moderating effects of Organization and Structure in Chinese firms. The International Journal of HUman Resource MAnagement, 22(1), 19-33. 